\title{
Islam and Syncretism in Java: Reflections on the Thought of Geertz and Woodward
}

\author{
Yusnia I'anatur Rofiqoh, Ach. Tofan Alvino, Asmi Chusae, Yasyva Agfa Nizar \\ Universitas Islam Negeri (UIN) Sunan Ampel Surabaya \\ Contactemail: ianayusnia@gmail.com
}

Received: Dec 04, 2020 | Revised: Feb 11, 2021 | Approved: April 29, 2021

\begin{abstract}
This article aims to revisit the concept of Javanese Islam in the thinking of Gertz and Woodward. This study is not a comparative study of the two figures but rather a criticism of Geertz's thinking using Woodward's thinking. Geertz stated that Islam in Java is considered a practice that deviates from Islamic values and teachings. Geertz's grouping of religious typology, namely Priyayi, Abangan, and Santri, is also problematic. Priyayi and abangan groups are considered followers of mystical teachings (kejawen), while the santri group adheres to pure Islam. Meanwhile, Woodward explains Javanese Islam with the theory of mystical Islam (Islamic Sufism). Woodward divides it into three essential characteristics: first, to believe in God Almighty, second, to be mystical, and third, to have a syncretic character. According to Woodward, there is only one Javanese religion, and the binding factor is Islam, not Java, as Geertz's statement.
\end{abstract}

Keywords: Acculturation, Javanese Islam, Mystical Culture

\begin{abstract}
Abstrak: Artikel ini bertujuan untuk meninjau kembali konsep Islam Jawa dalam pemikiran Gertz dan Woodward. Kajian ini bukan merupakan studi komparasi dari kedua tokoh, melainkan suatu kritik terhadap pemikiran Geertz dengan menggunakan pemikiran Woodward. Geertz menyatakan bahwa Islam di Jawa di anggap sebagai praktik yang menyimpang dari nilai-nilai dan ajaran Islam. Pengelompokan tipologi keagamaan yang dibuat oleh Geetz sendiri yaitu Muslim Jawa Priyayi, Abangan dan juga Santri juga problematis. Kelompok Priyayi dan Abangan dianggap sebagai penganut ajaran mistik (kejawen) sedangkan kelompok Santri menganut Islam murni. Sedangkan Woodward menjelaskan Islam Jawa dengan teori Islam mistik (sufisme Islam). Woodward membaginya menjadi tiga karakteristik yang mendasar: pertama, Percaya kepada Tuhan yang maha Esa, kedua, bercorak mistik dan ketiga, bercorak sinkretis. Menurut Woodward, agama Jawa itu hanya satu, dan faktor pengikatnya adalah Islam, bukan Jawa, sebagaimana pernyataan Geertz.
\end{abstract}

Kata Kunci : Akulturasi, Islam Jawa, Budaya Mistik 


\section{Islam and Syncretism in Java...}

Rofiqoh et.al, 2021

\section{Introduction}

Acculturation Islam is a mixed Islamic culture and local culture that makes Javanese Islam. This is what makes Javanese Islam a unique and different Islam from Islam in general. Islam and local culture itself synergize with each other and creatively enrich the mosaics in Indonesian civilization (Woodward, 1999). In this case, the integration of Islam in local culture does not make Islam adaptive. However, it leads to an acculturative change because there is not just a process of imitating each other or adapting in one respect to another. However, from a local culture that is collaborated with eastern Islamic culture. the middle and the two entities are made into a new unit (Syam, 2005).

Cultural Islam in the local area has a variation that can be called new in Islamic studies that are unique and distinctive, such as Minang Islam, Javanese Islam, Madurese Islam, Sasak Islam, Sundanese Islam, and Malay Islam and many other variants of Islam. This variation of Islam is not from pure Islam but is an Islam that has acculturated in the local culture (inculturation). In this case, inculturation is considered as a process in which new teaching is internalized and included in a local context or culture in the form of an adaptation or an accommodation (Misbahuddin, 2018). An intercultural thing is done to maintain an identity within oneself. With that, the roots of ideology in Islam are not mixed with this and the local culture that exists is not lost with the existence of Islam in it (Jamhari, 2014); (Paisun, 2010).

Javanese culture, especially in the era of the nineteenth century, had a fluctuating relationship between Islam and the acculturative face of Javanese Islam; there was more domination in the diversity of Muslim communities in the region, so that "racism" and tolerance of religions became a distinctive cultural character of Javanese Islam (Sumbulah, 2012). Islam itself has existed in Indonesia for centuries; this makes the arrival of Islam in Indonesia a fundamental process where Islam itself is currently the country with the highest Muslim majority in Indonesia. Before becoming the majority religion in Indonesia Islam could have two processes that occurred in contact between Islam and also the local community where it could be that the natives had direct contact with followers of the Muslim religion. Then they carried out a conversion, and there were also those where foreigners from Arabs, Indians and also Chinese who have embraced Islam first and finally live permanently in several parts of Indonesia itself and 
marry with the local people and then mingle with the lifestyle that occurs in the local community (Ricklefs, 2009).

A commentary notes that Islamic interpretation has riches such as literature, science, philosophy, hermeneutics, art, medicine, and theater which enrich a view in Islam (Halkin, 1956). In the Hellenistic civilization (Greek and Roman) in medieval Islam had many benefits where there was a leap in Islamic civilization to enter all corners of the world. The Islamic teachings that are sourced from the Al-Quran and the Hadith are enriched with a hybrid view where both are interpreted and translated into various languages (Soeratman, 2000).

In history, the theory of the indigenization of Islam in Java itself basically has a very smooth process and occurs in a short time without coercion and easily mingles with local communities and centers in a kingdom (Soeratman, 2000). In general public institutions, the process of indigenous people did not run as fast as in the royal centers because the elite indicated social change. After all, the king and the ruling structure could determine a series of rules and in this case Islam in the palace itself interpreted Islam in the framework of Javanese culture (Ricklefs, 1974).

The Keraton's world view of Islam also influences public perception and awareness (Soeratman, 2000). The local community themselves taught in the Islamic teachings of the palace is considered actual teaching in Islam. Although Ulama must be advisers to the king in a palace structure, the scholars themselves do not directly determine practical lines in the king's life and his family and his policies. Kings and palaces carry out Islamic teachings selectively. Although they have the title of sultans obtained through the blessing of the ruler or caliph in Mecca and have the position of Sayidin Panatagama, they only do zakat and fast, but do not pray five times a day and are not interested in performing the pilgrimage to Mecca (Kartodirjo, 1997).

In this case, it shows that the interpretation of the palace and Islam as the holder of hegemony and the meaning of Islam has adapted to Javanese values. Nevertheless, this does not apply to all officials and residents of the palace. The specific Javanese cultural values imaged by the palace are valid if Islam is syncretic, although not in a specific or absolute sense. However, in this case, racism does not only occur in Islam but also in Hinduism, Buddhism, and Christianity. The legacy of history over the centuries 


\section{Islam and Syncretism in Java...}

Rofiqoh et.al, 2021

has not entirely disappeared. There is an "eternal idea" which remains in Javanese customs even though it lives and develops according to the times (Groeneveld, 1960).

As it is known that Islam had spread during the Majapahit era, especially on the north coast. King Hayam Wuruk (1350-1389) with Gadjah Mada (1364) had contact with Islam which was spread through traders in ports (Dale, 1980). It is just that, as a religion of newcomers, Islam has not yet shown its teeth. Islam coexists with Hinduism, Buddhism and the native Javanese religions (Mulyana, 2005). In this case, Islam in its spread does not directly teach the central teachings of Islam. Nevertheless, there is a compromise between Islam and local culture. The new followers of Islam are from societies that previously embraced Hinduism, Buddhism, and Animism and dynamism. Of course, these converts find it challenging to leave traditions passed down from generation to generation by previous ancestors. Adaptation, acculturation and inculturation continue to occur and form Islam and a new order, mainly carried out on the island of Java. There is the Indigenousization of Islam on the land of Java (Ricklefs, 2009).

In this case the indigenization of Islam itself is a stage of understanding the local Javanese community about Islam. Since then, the King of Mataram Islam did not ask for legitimacy from the Hindu and Budha breeds but directly from the caliphs in Mecca. To enlarge the kings' legitimation, Islamic symbols began to be made in addition to the typical Javanese symbols. In the Babad Tanah Jawa story, the kings of Mataram are associated with descendants of the prophets (Woodward, 1999). This serves the purpose of legitimacy and can add to authority. Islamic praxis and its set of teachings have gradually begun to accumulate and become the privatization of Islam; because of this, it is very intense at this level. Moreover, Islam developed in Java is a dimension of Sufism or the mind, so worship of symbols is more dominant (Fauzi, 2012). The dimension of Sufism or esoteric Islam emphasizes harmony between God, humans and nature. Meanwhile, the exoteric or fiqh dimension emphasizes legal aspects and is more stringent. This esoteric Islamic practice is more dominant in court life (Dwijayanto, 2017). In this case, Javanese Islamic practice is more directed towards Sufism, which emphasizes the closeness of God, humans and nature and is a characteristic of local Islamic culture. Suppose the indigenization of Islam is placed in the context of Javanese 
culture. This can be interpreted as a process of mutual adoption or a meeting between Islamic elements and local Javanese elements. These two things negate each other and enrich each other and the role of the carriers of Islam to Java (the Walisongo are significant). Where they choose Islamic interpretations that culture between pure Islam and local culture, understanding, in this case, refers itself to the context of Javanese culture (Salim, 2013). The Walisongo themselves are aware that Java has a rich tradition and its long civilization is not just an empty blank. However, Java is another reality where the wealth of traditions and norms in life are no worse than religious traditions. The privatization of Islam in Java is a natural process that cannot be stopped and this process also occurs in other areas of Islam, which acculturates itself with the populated areas of Africa, India, South Asia, Europe, America, Australia and Southeast Asia, where all of these areas are civilized. In this case, the intellectual interaction between Islam and local culture gave birth to a new and more insightful Islamic treasure (Fakhry, 1997).

\section{Research Methods}

This study using library data as a source of analysis. These data are primarily in the form of works by Mark R. Woodward, both those that have been recorded and distributed from journals that have been published, including Javanese Islam: Normative Piety Versus Mysticism in the Sultanate of Yogyakarta, Toward A New Paradigm: Recent Developments In Indonesian Islamic Thought, Java, Indonesia and Islam and The "Slametan": Textual Knowledge and Ritual Performance in Central Javanese Islam. Meanwhile, secondary data journal writings from various domains as far as they are relevant to the focus of discussion in this study primarily works on Javanese Islam. In this case the data collection technique is done by tracing the data both in books and journals that discuss Islamic Acculturation in Java. After the data is collected, it is described and analyzed according to the study's object. In this analysis, the authors use an interpretive descriptive approach, namely by tracing and uncovering the Javanese Islamic conception in Woodward's thinking, which criticizes the Islamic concept previously proposed by Gertz. In addition, the method of internal coherence will also be used, namely by looking at concepts and aspects based on their harmony with each other and determining the core ideas that are fundamental to Woodward's 


\section{Islam and Syncretism in Java...}

Rofiqoh et.al, 2021

thoughts on Javanese Islam. This research is not a comparative study of the two figures but rather a criticism of Geertz's thinking using Woodward's perspective. In this case, the researcher places Woodward's thoughts as a research subject to criticize the conception of Javanese Islam that we have accepted so far. This research uses library research where the research location is taken from the research made by Mark $\mathrm{R}$. Woodward where Mark researches Islam in Java and the research location is taken from the Yogyakarta Sultanate. This type of research data source is the primary data source in library such as journals and books. To obtain and achieve the data, the choice of literature accuracy supports obtaining validation and data quality.

This research uses critical discourse analysis in which this theory is an exciting method of analysis because of its association with social conditions, culture, ideology, and absolute hegemony in society (Meyer, 2001). Discourse analysis is a study that examines and analyzes the language used naturally, both in verbal and written form. The use of natural language is explained in everyday communication. In theory, language information is a tool that can convey a sign and the delivery of an object in conversation, speech and speech.

Of the many discourse analysis models introduced and developed by several experts, Van Dijk's model is most widely used. Van Dijk's critical discourse analysis model analyzes the text and sees how the social structure, domination and power groups exist in society and how cognition or thoughts and consciousness shape and influence the text being analyzed. Van Dijk describes discourse in three dimensions or structures: text, social cognition, and social context. The essence of the analysis of Van Dijk's theory is to combine the three dimensions of discourse into a single analysis. His approach to analyzing various ideologies has three parts: social analysis (investigating all social structures or known as context), cognitive analysis, and discourse analysis mainly based on text (syntax, lexicon, local semantics, themes, schematic structures).

\section{Literature Review}

To complement the references and development of this research, researcher study what other researchers have done with the focus of this research, as material in this research, such as previous research on Javanese Islam was conducted by (Ramli, 
2005) focuses on the tradition of Sufism, which is known as a theory that emphasizes mysticism, namely orthodox and heterodox which refers to Al-Ghazali and Al Junaydi and Al-Hallaj. The difference with the current research is that it lies in the focus of the research where this research method is more directed towards research on Mark R. Woordwad's refutation of the idea of Islamic syncretism in Java by proposing an antithesis in the form of acculturated Islam based on research in the city of Solo.

Subsequent research was conducted by (Yaqin, 2019) which focuses on religion as part of a cultural system and also discusses how religious behavior can be considered a social phenomenon. This previous research used qualitative research. The results of this study are to reveal Javanese Islam as a theoretical understanding where. This study looks at how religion becomes a part of a cultural system that is mainly related to Islamic typology in a local context with a syncretic pattern.

Another research was conducted by (Muqoyyidin, 2013) describes the problem between the dynamics of cultural Islam that exists, grows, and develops in Indonesia, especially those related to the dialectic between Islam and local Javanese culture, and this research refers more to Cultural Sociology. The results of this study explain that Javanese Islam has a unique character and expression of diversity. This is because the spread of Islam in Java is more dominant in acculturation.

Previous research was conducted by (Fuad, 2019) explains how the mataraman tradition is in the dialogical process between Islamic culture and the Islamic religious tradition of Mataraman. This research shows that the Mataraman tradition is related to the Mataram kingdom from a regional perspective and a socio-political perspective influenced by the Mataram kingdom, both pre-Islamic and up to the Islamic era. Most identical in terms of language. There are many similarities with the Mataram kingdom in terms of religious tradition, such as the traditions of Sekaten, Grebek, Tahlilan, Surowan, and Nyadranan and these traditions were modified by Walisongo in his da'wah strategy of spreading Islam in Java. Further research was conducted by (Ismail, 2013) shows that the symbols of Javanese Islamic da'wah brought by Walisongo and its later generations have social attributes to construct a conservative discourse that is often termed traditional feudalism towards critical modernity. Furthermore, sociological analysis of culture from various events of Islamic trends in Java is directed 
at efforts to reveal the meanings of the symbols and reveal the grammar behind the emergence of the phenomenon itself.

\section{Discussion}

\section{Javanese Islamic Acculturation}

For centuries, Islam has shown its existence. The arrival of Islam in Indonesia is an essential process before Islam became the religion of the majority in Indonesia. The study of how Javanese Islam has received significant attention, wherefrom the many kinds of research on Javanese Islam, one of the most famous studies is the research conducted by Clifford Geertz where the work which sparked Abangan, Santri and Priyayi in Javanese society greatly influenced the construction of Javanese Islam although along with it it has received much criticism from other researchers in the closing section of Geertz himself highlighting what Geertz's concepts are like between what is called religion and adat. This distinction is essential in obtaining a clear understanding of Javanese rituals as part of religion or what is meant simply as customary rituals (Geertz, 1981).

Islam in Java in the context of writing is a system of worship and local beliefs that is different from the Islamic tradition in general. In this case, it can be seen that Islam in Java gives a new color to the Islamic world. Javanese Islam itself absorbs the local culture and changes the misleading cultural context into a culture in acculturating local culture with Islamic values (Dwijayanto, 2018). This is also what makes and absorbs and even Islamizes indigenous cultures and promotes the holy book. The development of various aspects of the religiosity of the Javanese Islamic community, including faith, rituals, and beliefs, cannot be separated from the region and time in which the community is located. As a form of acculturation, it can be seen from various cases. The growth before Islam was interpreted by Islam itself as a realia that elaborated the elements of the local tradition and the textual concept in carrying out vertical and horizontal awareness. The relationship with the Creator is ritualized and with fellow humans as a form of social interaction (Esposito, 2001).

Indonesian Muslim scholar, Nur Syam suggests that the development of the Islamic community, especially in Java, is integrated into various social spaces, one of 
which is the coastal community of Java. The formation of patterns and typology from an Islamic perspective makes a difference in categorizing society. The stigma against Javanese Islam originating from Java is not absolute. However, there are many crossovers and elaborations between local culture and foreign (Arabic) culture, which then make a social interaction among Javanese society, representing the diversity of Islam in Java (Syam, 2005).

The development of Islam in Java cannot be separated from the various traditions in the area. Existing traditions interact with Islam in Java or vice versa Islam interacts with traditions in Java (Rahman, 2012). The dialectic between a religio cultural and a religio social is quite a tiring process for the Javanese Muslim community. This matter impacts local Islamic traditions that reflect behavior in a textual context and daily behavior and interactions (Yaqin, 2019). The reciprocal relationship between environmental, social life, and various probabilities is the beginning of forming these interaction patterns. Religious activities are often juxtaposed with common interests due to the social environment that demands uniformity and the role of religion itself which makes people shape their respective characters, as is the case with the social environment in pesantren (Yaqin, 2019).

\section{Mystical Islam in Java}

The noble culture that Geertz calls Priyayi and the indigenous peasants he calls Abangan are combined into one and are called "kejawen". Kejawen means Javanism or which emphasizes pre-Islamic heritage, or what is thought to be so. As a category, the term "kejawen" is subsequently opposed to the Islamist shift of the Santri. Mark Woodward, one of the scholars who use this opposition most often, argues that "Javanese religion," both in its form as a popular and mystical religion, is basically an adaptation of Sufism and is, therefore, a local embodiment of Islam. Thus, the opposition between Islam and Kejawen refers to nothing but divisions within Islam itself. According to Woodward, mysticism owes more to Ibn Arabi's theosophy than to the religions of the pre-Islamic Javanese era; the worship of saints and the implementation of Slametan by Javanese peasants can be found among famous Muslims in Asia and Southeast Asia (Nasir, 2019). Thus, the scale of cultural variation used is not the level of Islamization but the emphasis on different aspects of Islam. As a result, according to 
Woodward, there is only one Javanese religion, and the binding factor is Islam, not Java, as said Geertz (Bowen, 1993).

This contradicts what Geertz understands about Javanese religion as syncretic; In Geertz's view, Javanese Islam is nominal, and Javanese influence is much more dominant. Therefore, according to Azram (2013), Geertz is reluctant to use Javanese Islam or Islam in Java. Geertz prefers the term "Javanese religion." Reading Geertz's monumental work, The Religion of Java, we cannot dismiss the fact that he considered the syncretism that was developing strongly in Java to be a bad thing, and this is why, in his view, Islam in Java is not the real Islam. It is very contrary to the views of scholars who discuss the same issue. For this last group of scholars, syncretism is valued as a way how people can make peace with their differences. Slametan, for example, what Geertz sees as the heart of what he calls; Javanese religion is an embodiment of the Javanese commitment to compromise, because this ritual is a gathering space for people who have different views and orientations, not only in matters of life in general and their views and understanding of the slametan itself (Bowen, 1993).

\section{Sufism and Normative Piety}

According to the idea of Mark R. Woodward, in analyzing the problem of normative piety in Java, one must understand and analyze the problems of normative piety and Sufism in a comprehensive manner. Normative piety itself is a set of behaviors that the Prophet Muhammad exemplified and described for Muslims. It consists of obedience and form of behavior being the main thing. While Sufism itself emphasizes mental roles rather than inner behavior. His orientation is to free himself from matters concerning lust and worldly desires. There is a continuum of things that becomes a differentiator to make humans have an image manifestation and ultimately return to God. A traditional social and political cosmological thought within the scope of Javanese society plays a dominant role in shaping a normative rule in Islam. This can be seen from the wali Songo who elaborate the understanding of culture and religion. Meanwhile, the rituals of the santri and society, in general, are new people who believe in normative law as an essential rule for them. In this case, Islam becomes normative 
and must understand most religious orientations or forms of piety rather than as a mixed sociology category (Sururin, 2007).

\section{The Yogyakarta Palace and Symbol of Sufism}

In the pre-independence era, the Yogyakarta Palace had firm control, including tradition and culture which had a powerful and highly developed influence. According to Haine Gedem, the city represented a mystical Sufi theory designed to reflect social and political reality in the Islamic Sultanate of Yogyakarta. The tradition of court religion continues to apply dynastic legitimization, where the kraton itself is a complete resource for studying the role of Sufism in Javanese politics and the role of the kraton in a political theory. The palace itself is considered the mystical center and spiritual body of the sultanate as a forum for realizing a divine essence represented by the sultan. He is the axis mundi of Yogyakarta. The Sultan himself is a ritual practitioner in the force of dynastic kesakten. God's blessings are spread to the residents in the kingdom in that it embodies the transcendent and immanent characteristics of God (Sururin, 2007).

\section{Javanese Islamic Tradition in Woodward's Perspective}

Any discussion about Javanese religion must involve the famous Clifford Geertz typology related to the three Islamic categories of Javanese Santri, Abangan, and Priyayi society. According to Geertz, the Islamization of Java, which began in the 13th century, occurred partially and constantly changes. Devout Muslims, whom he calls "Santri," live in the northern coastal areas, both in rural areas, where traditional Islamic educational institutions are developed and urban traders. Meanwhile, what Geertz calls the "Abangan" culture among the majority of peasants, are those who, although embracing Islam, is only nominal, because they are still bound by Javanese animism and ancestral traditions. The traditional middle class who generally live in the city are also nominal, because they still practice mysticism taken from the Hindu-Buddhist era, before the arrival of Islam in Java. These aristocratic bureaucrats and those who adopted their lifestyle Geertz called "Priyayi" (Sumbulah, 2012).

Some of the commentators on these Gertzian terms made slight "modifications", and found several sub-variations within these categories (Geertz, 1981). Some people claim that "Priyayi" is a social class or group status, not a subculture like the other two 
variants. There is confusion about whether the terms santri and abangan are just categories or can designate certain groups. However, the discussion on this subject is moving on. The general trend is to replace the three dimensions of Geertz's cultural variation with a sharper dichotomy based on their degree of Islamic participation (Koentjaraningrat, 1994).

Such attempts to claim Java for Islam were motivated, for one thing, and used to counter biased scholarship due to the liberal antipathy to Islam. This resistance movement began to occur in the Asian studies environment, as did Bowen (1993) and Roff (1985). Furthermore, Woodward (1988) also argues that slametan is the fundamental religion of Java: First, it results from interpretations of Islamic texts and ritual methods carried out by a group of Muslims who are not native to Java. Second, especially in Central Java, slametan is not a ritual typically performed in rural areas but instead imitates the religious practices of the imperial Yogyakarta palace, whose inspiration is Sufism. In other words, the forms and meanings of slametan originate from Islamic texts as interpreted by the religious practice of the palace (state cult). Woodward's scripturalist view differs sharply from Geerty's view of the Javanese religious core ritual slametan as rooted in the animist tradition of the peasants (Geertz, 1981).

Despite agreeing with Geertz on several matters related to Javanese religious typology, Beatty (2004) criticizes Geertz's explanation of Slametan at the beginning of his book, The Religion of Java: (at the center of the whole Javanese religious system there is a small ritual that is simple, formal, not dramatic, and almost in hiding [for fear of causing trouble]: Slametan). So, according to Geertz, although it is the essence of Javanese religion, Slametan is carried out to keep quiet for fear of causing problems. What is the problem? It could be that the problem Geertz meant was the problem that would be caused by the reaction of the more orthodox people to Islamic practices that are still thick with local cultures. Implicitly, Geertz admits that among the Javanese people, there are also more orthodox variants in their Islamic terms, or even the phenomenon of Islamic orthodoxy is more dominant, causing Javanese people to practice slametan, especially with elements Javanese is still thick, must do it a little secretly so as not to attract attention (Geertz, 1960). 


\section{Conclusion}

The study of Javanese Islam presents the complexity of meaning in various perspectives, especially from the thoughts of Geertz and Woodward. As previously described in this paper, the guidelines for the view on the concept of Javanese Islam show that Javanese Islamic Studies are always dynamic in the area of the cultural, social, and political life of Javanese society. Javanese Islam is called unique not because it maintains the cultural aspects of religion but because of the mystical concept formulated by the state in power (Imperial Culture) and eventually becomes the citizens' religion. Limiting attempts at limiting the critique of Geertz's and Woodward's ideas will make them a more relevant concept throughout the ages.

\section{References}

Bowen, J. R. (1993). Muslims through Discourse: Religion and Ritual in Gayo Society. Princeton University Press.

Dale, S. F. (1980). Islamic Society and the South Asian Frontier: The Mappilas of Malabar 1498-1922. Oxford University Press.

Dwijayanto, A. (2017). PRIBUMISASI ISLAM NUSANTARA: ANTARA NALAR BERAGAMA DAN GERAKAN SOSIAL KEAGAMAAN DI INDONESIA. QALAMUNA: Jurnal Pendidikan, Sosial, Dan Agama, 9(02), 71-92.

Dwijayanto, A., \& Rohmatulloh, D. (2018). PONOROGO, THE LITTLE JAVA: POTRET KEBUDAYAAN DAN KEBERAGAMAAN MASYARAKAT MUSLIM PONOROGO ABAD XX. Al-Adabiya: Jurnal Kebudayaan Dan Keagamaan, 13(01), 1-31.

Jamhari, J. (2014). Javanese Islam: The Flow of Creed. Studia Islamika, 9(2).

Esposito, J. L. (2001). Ensiklopedi Oxford Dunia Islam Modern Jilid I. Mizan.

Fakhry, M. (1997). A Short Introduction to Islamic Philosophy, Theology and Mysticism. Oneword.

Fauzi, M. (2012). TRADITIONAL ISLAM IN JAVANESE SOCIETY: The Roles of Kyai and Pesantren in Preserving Islamic Tradition and Negotiating Modernity. JOURNAL OF INDONESIAN ISLAM, 6(1), 125-144.

Fuad, A. J. (2019). Tlatah Dan Tradisi Keagamaan Islam Mataraman. Jurnal IAIT Kediri, Vol. 30 No.1, 15. 
Geertz, C. (1960). The Religion of Java. The University of Chicago Press.

Geertz, C. (1981). Abangan, Santri, Priyayi dalam Masyarakat Jawa. Pustaka Jaya.

Groeneveld, W. P. (1960). Historical Notes on Indonesia and Malaya: Compiled From Chinese Sources. C. V. Bhatara.

Halkin, A. S. (1956). The Judeo-Islamic Age, The Great Fusion" dalam Leo W. Schwarz, ed., Great Ages and Ideas of the Jewish People. The Modern Library.

Ismail, M. (2013). Strategi Kebudayaan: Penyebaran Islam Di Jawa. Jurnal Kebudayaan Islam, Vol. 11 No.1, 14.

Kartodirjo, S. (1997). 700 Tahun Majapahit (1293-1993). Dinas Pariwisata Propinsi Daerah Tingkat I Jawa Timur.

Koentjaraningrat. (1994). Kebudayaan Jawa. Balai Pustaka.

Misbahuddin, M. (2018). Pembangunan Budaya Dalam Masa Islam Awal. Al-Adabiya: Jurnal Kebudayaan Dan Keagamaan, 13(02), 332-347.

Mulyana, S. (2005). Runtuhnya Kerajaan Hindu-Jawa dan Timbulnya Negara-Negara Islam di Nusantara. LKiS.

Muqoyyidin, A. W. (2013). Dialektika Islam Dan Budaya Lokal Jawa. Jurnal Kebudayaan Islam, Vol. 11 No.1, 21.

Nasir, M. (2019). Revisiting the Javanese Muslim Slametan: Islam, Local Tradition, Honor and Symbolic Communication. Al-Jami'ah: Journal of Islamic Studies, 57(2), 329-358.

Paisun. (2010). Dinamika Islam Kultural: Studi atas Dialektika Islam dan Budaya Lokal Madura. Jurnal el-Harakah, Vol. 12 No.12, 156.

Rahman, A. A. (2012). Akulturasi Islam dan Budaya Masyarakat Lereng Merapi Yoyakarta: Sebuah Kajian Literatur. Jurnal Indo-Islamika, Vol. 1 No.2, 157.

Ramli, M. (2005). Pemikiran Islam Jawa Menurut Mark R. Woodward [Skripsi]. UIN Sunan Kalijaga.

Ricklefs, M. C. (1974). Yogyakarta Under Sultan Mangkubumi 1749-1792: A History of the Division of Java. Oxford University Press.

Ricklefs, M. C. (2009). Sejarah Indonesia Modern 1200-2008, terj. Tim Serambi. Serambi.

Soeratman, D. (2000). Kehidupan Dunia Keraton Surakarta 1830-1939. Yayasan Untuk Indonesia. 
Sumbulah, U. (2012). Islam Jawa dan Akulturasi Budaya: Karakteristik Variasi dan Kataatan Ekspresif. Jurnal el-harakah, Vol.14 No.1, 51.

Sururin. (2007). Islam In Java Normative Piety and Mysticism in the Suntanate of Yogyakarta. Jurnal Al- Maktabah, Vol. 9 No. 1, 113.

Salim, A. (2013). Javanese religion, Islam or syncretism: comparing Woodward's Islam in Java and Beatty's Varieties of Javanese Religion. Indonesian Journal of Islam and Muslim Societies, 3(2), 223-266.

Syam, N. (2005). Islam Pesisir. LKiS.

Woodward, M. R. (1989). Islam In Java Normative Piety and Mysticism in the Suntanate of Yogyakarta. The University of Arizona Press.

Woodward, M. R. (1988). The" Slametan": Textual Knowledge and Ritual Performance in Central Javanese Islam. University of Chicago Press.

Woodward, M. R. (2010). Java, Indonesia and Islam. Springer Science \& Business Media.

Yaqin, H. (2019). Islam Jawa: Lokalitas dalam Konteks Keindonesiaan. Jurnal Humanistika, Vol. 5 No. 2, 17. 